\title{
PENGARUH LAMA PERENDAMAN CETAKAN ALGINAT DI DALAM LARUTAN DESINFEKTAN GLUTARALDEHID 2\% TERHADAP STABILITAS DIMENSI
}

\author{
Eki Dyan Larasakti Santoso ${ }^{\star}$ Teguh Tri Widodo**, Moh. Baehaqi ${ }^{* *}$
}

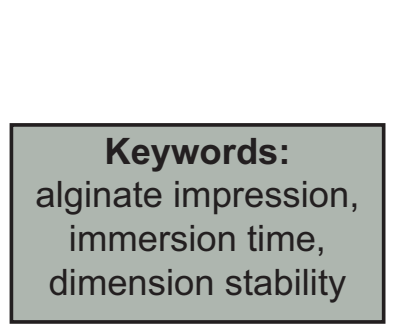

\section{ABSTRACT}

Background: Blood and saliva are the media for bacteria to accumulate, and it can stick to the surface of a alginate's impression during the molding process. Immersion with glutaraldehyde is one of the impression material desinfectant method since glutaraldehyde is spatially as bacterisid and fungisid. Something that must be considered when performing disinfection is the disinfection technique, as it would affect the dimension stability of impression materials. The aim of this research was to know the influence of immersion time in solution $2 \%$ glutaraldehyde disinfectant againts dimension stability. Method: The type of this research was quasi experimental using 30 samples, which were divided into five groups each containing 6 samples. The samples of alginate's impression were immersed in disinfectant solution of glutaraldehyde $2 \%$ respectively for $5,10,15,20$ minutes and also without immersion as the control group, then conducted a horizontal dimension stability measurement is the diameter of the die by using a digital caliper. Data were analyzed by one-way Anova test. Result: The result of this research were obtained a significance $(p<0,05)$ between horizontal dimension stability of alginate's impression without immersed and horizontal dimension stability of alginate's impression after immersed for 5, 10, 15 and 20 minutes. Conclusion: Conclusion of this research was there was an influence of immersion time alginate's impression in disinfectant solution glutaraldehyde $2 \%$ againts dimension stability.

\section{PENDAHULUAN}

Bahan cetak dalam kedokteran gigi bervariasi jenisnya yaitu bahan cetak yang bersifat elastis dan non elastis. Salah satu bahan cetak elastis yang banyak digunakan di kedokteran gigi adalah hydrocolloid irreversible atau alginat ${ }^{1}$. Alginat banyak digunakan karena mudah dalam pembuatannya, harga yang relatif murah dan keakuratannya memuaskan². Alginat juga banyak digunakan karena lebih luas indikasi pemanfaatannya dibandingkan jenis bahan cetak lainnya ${ }^{3}$.

Alginat mengandung $85 \%$ air yang rentan terhadap distorsi. Cetakan alginat dapat mengalami sineresis yaitu menguapnya air bila terjadi kenaikan suhu atau bila disimpan di udara terbuka dalam waktu tertentu sehingga cetakan alginat akan mengalami kontraksi. Cetakan alginat juga bersifat imbibisi yakni menyerap air bila berkontak dengan air dalam waktu tertentu sehingga akan mengembang ${ }^{4}$.

Penyebaran infeksi dalam rongga mulut dapat melalui darah, saliva, atau jaringan infeksius lainnya ${ }^{5}$. Saat pencetakan darah dan saliva dapat menempel pada permukaan bahan cetakan, hal ini dapat menjadi sumber terjadinya kontaminasi silang. Mikroorganisme dari rongga mulut dapat bertahan pada permukaan hasil cetakan dan dapat berpindah ke model stone. Mencuci atau membilas hasil cetakan dengan air yang mengalir tidak sepenuhnya menghapus adanya 
mikroorganisme pada permukaan hasil cetakan ${ }^{6}$, oleh karena itu terdapat pedoman pengendalian infeksi dalam perawatan kesehatan gigi bahwa semua hasil cetakan harus dibersihkan, didesinfeksi dan dibilas menggunakan larutan disinfektan sebelum ditangani di laboratorium.

Terdapat dua metode yang disarankan untuk mendesinfeksi bahan cetak yaitu metode perendaman atau penyemprotan dengan bahan desinfektan ${ }^{8}$. Metode perendaman digunakan $77 \%$ dokter gigi di Hongkong untuk mendesinfeksi bahan cetak $^{9}$. Desinfeksi dengan perendaman telah diakui lebih efektif dibandingkan dengan penyemprotan. Larutan desinfektan dapat menjangkau seluruh permukaan hasil cetakan pada proses desinfeksi dengan perendaman ${ }^{6}$.

Glutaraldehid merupakan salah satu desinfektan yang paling umum digunakan dari kelompok aldehid yang memiliki sifat bakterisid, fungisid dan dapat membasmi virus dan telah efektif sebagai desinfektan untuk bahan cetak alginat dan silikon ${ }^{8}$. Saat melakukan desinfeksi faktor penting yang harus diperhatikan adalah pengaruh teknik desinfeksi terhadap stabilitas dimensi bahan cetak $^{6}$, karena ketepatan hasil cetakan merupakan faktor yang sangat penting ${ }^{10}$. Perendaman cetakan alginat dalam larutan desinfektan iodine $1 \%$ dan isophrophyl alcohol terjadi perubahan dimensi hasil cetakan terbesar pada lama perendaman 20 menit $^{10}$.

Penelitian ini bertujuan untuk menganalisis pengaruh lama perendaman cetakan alginat dalam larutan desinfektan glutaraldehid $2 \%$ terhadap stabilitas dimensi.

\section{METODE PENELITIAN}

Jenis penelitian yang digunakan adalah quasy experimental, dengan rancangan post-test only control group design. Terdapat 1 kelompok kontrol dan 4 kelompok perlakuan. Populasi dalam penelitian ini adalah model/die dari dental stone yang merupakan koleksi lab FKG Unissula. Lama perendaman yang digunakan untuk merendam cetakan alginat di dalam larutan disinfektan glutaraldehid $2 \%$ adalah $5,10,15$ dan 20 menit. Stabilitas dimensi dalam penelitian ini adalah stabilita dimensi horizontal yaitu panjang diameter die dalam satuan $\mathrm{mm}$.

Penelitian ini dilakukan dalam 1 hari. Pengenceran larutan glutaraldehid 2,45\% menjadi $2 \%$ yaitu dengan menambahkan akuabides steril sebanyak $275,5 \mathrm{ml}$ ke dalam larutan glutaraldehid 2,45\% 1224,5 $\mathrm{ml}$. Menakar bahan cetak dengan P/W ratio $1: 2$ yaitu $84 \mathrm{gr}$ alginat dan $200 \mathrm{ml}$ air. Dilakukan pengadukan oleh 6 orang dengan menggunakan rubber bowl dan spatula dengan instruksi pengadukan dihentakkan dan ditekan pada dinding rubber bowl dengan putaran intermiten $180^{\circ}$ secara bersama-sama. Setelah bahan cetak bercampur homogen, bahan cetak alginat diisi ke dalam 6 cetakan, kemudian dilakukan pencetakan pada master die. Setelah bahan cetak mengeras, master die dilepas dari masingmasing cetakan dan segera diisi dengan dental stone yang telah diaduk dengan $\mathrm{P} / \mathrm{W}$ ratio $1: 1$ dengan menggunakan alat vibrator, sehingga didapatkan sampel yang digunakan sebagai kelompok kontrol. Membuat 6 sampel seperti diatas, sebelum diisi dengan dental stone cetakan direndam selama 5, 10, 15 dan 20 menit di dalam larutan desinfektan glutaraldehid $2 \%$. Setelah hasil cetakan direndam dalam larutan desinfektan dengan variasi lama perendaman berbeda, dilakukan pengisian hasil cetakan dengan dental stone memakai alat vibrator. Model die yang diperoleh diukur stabilitas dimensi horizontal yaitu panjang diameternya dengan menggunakan kaliper digital.

Penelitian ini dilakukan di laboratorium Kimia FK Unissula dan Laboratorium FKG Unissula, Semarang. Data yang diperoleh dianalisis dengan One-way Annova, yang sebelumnya diuji normalitas dan homogenitasnya menggunakan Shapiro 
wilk dan Lavene's test.

\section{HASIL PENELITIAN}

Peneliti mengambil sampel sebanyak 30 die stone yang dibagi ke dalam 1 kelompok kontrol dan 4 kelompok perlakuan. Masing-masing kelompok berisikan 6 die stone. Hasil penelitian mengenai pengaruh perendaman cetakan alginat di dalam larutan desinfektan glutaraldehid $2 \%$ terhadap stabilitas dimensi dengan variasi waktu yang berbeda dapat dilihat pada tabel 1 . banyak faktor misalnya, gerakan selama proses gelasi berlangsung atau gerakan melepas alginat dari cetakannya yang tidak tepat ${ }^{11}$, metode disinfeksi juga ikut berpengaruh ${ }^{12}$. Imbibisi lebih dipengaruhi oleh material yang terkandung di dalam alginat itu sendiri yang terjadinya tidak dapat dicegah ${ }^{11}$.

Berdasarkan penelitian yang telah dilaksanakan peneliti menggunakan die dengan lima jenis perlakuan yaitu cetakan alginat yang tidak direndam sebagai kelompok kontrol dan cetakan alginat yang

Tabel 1. Hasil pengukuran perubahan dimensi cetakan alginat

\begin{tabular}{lc}
\hline Lama perendaman & Mean \pm SD \\
\hline Kontrol & $30,79 \pm 0,11$ \\
5 menit & $30,74 \pm 0,23$ \\
10 menit & $30,68 \pm 0,07$ \\
15 menit & $30,60 \pm 0,07$ \\
20 menit & $30,57 \pm 0,12$ \\
\hline
\end{tabular}

Tabel 2. Hasil Uji Post Hoc LSD

\begin{tabular}{llcc}
\hline $\begin{array}{l}\text { (I) lama } \\
\text { Perendaman }\end{array}$ & $\begin{array}{l}\text { (J) lama } \\
\text { perendaman }\end{array}$ & $\begin{array}{c}\text { Mean } \\
\text { Difference (I-J) }\end{array}$ & Sig. \\
\hline Kontrol & 5 menit & 0,05167 & 0,505 \\
& 10 menit & 0,10667 & 0,175 \\
& $\mathbf{1 5}$ menit & $\mathbf{0 , 1 8 8 3 3}^{*}$ & $\mathbf{0 , 0 2 0}$ \\
& $\mathbf{2 0}$ menit & $\mathbf{0 , 2 1 8 3 3 ^ { * }}$ & $\mathbf{0 , 0 0 8}$ \\
5 menit & 10 menit & 0,05500 & 0,478 \\
& 15 menit & 0,13667 & 0,083 \\
& $\mathbf{2 0}$ menit & $\mathbf{0 , 1 6 6 6 7 ^ { * }}$ & $\mathbf{0 , 0 3 7}$ \\
\multirow{2}{*}{ menit } & 15 menit & 0,07833 & 0,315 \\
& 20 menit & 0,11167 & 0,156 \\
& 20 menit & 0,03333 & 0,666 \\
\hline
\end{tabular}

\section{DISKUSI}

Keakuratan dimensi model gips hasil pencetakan alginat dipengaruhi oleh direndam dalam larutan glutaraldehid $2 \%$ selama 5, 10, 15 dan 20 menit. Perubahan dimensi yang tidak bermakna terjadi pada 
Tabel 3. Hasil uji normalitas data menggunakan Uji Shapiro-Wilk

\begin{tabular}{ll}
\hline \multicolumn{1}{c}{ Lama perendaman } & Nilai p \\
\hline Kontrol & $0,719^{*}$ \\
5 menit & $0,607^{*}$ \\
10 menit & $0,826^{*}$ \\
15 menit & $0,477^{*}$ \\
20 menit & $0,752^{*}$ \\
\hline
\end{tabular}

cetakan alginat, baik yang direndam selama 5 dan 10 . Terjadinya hanya sedikit perubahan dimensi tampaknya berkaitan dengan lamanya waktu perendaman yang relatif singkat. Namun demikian, perubahan dimensi tetap terjadi karena struktur alginat berbentuk serat memiliki ruangan kapiler yang terisi dengan air $^{13}$.

Dalam penelitian ini, stabilitas dimensi alginat mulai berubah setelah direndam selama 15 menit, akan tetapi ketika dibandingkan dengan perubahan yang terjadi pada perendaman selama 20 menit, perbedaan tersebut tidak bermakna. Imbibisi terjadi karena cetakan alginat yang mengandung $85 \%$ air direndam dalam larutan glutaraldehid $2 \%$ yang juga mengandung air, seiring dengan bertambah lamanya waktu perendaman maka cetakan akan menyerap air dan terjadi ekspansi dimana dapat menyebabkan distorsi atau swelling (mengembang) dan bentuk hasil cetakan alginat tidak lagi memiliki dimensi yang stabil14. Hal tersebut juga dipengaruhi oleh sifat alginat sebagai bahan yang hidrofilik ${ }^{15}$.

Dari penelitian yang dilakukan terhadap 30 sampel penelitian, didapatkan hasil analisis statistik yang menunjukkan bahwa perubahan dimensi bahan cetak pada perendaman 5, 10 dan 15 menit masih dalam batas toleransi klinik, perendaman hasil cetakan dalam larutan desinfektan glutaraldehid $2 \%$ atau sodium hipokorit
$1 \%$ hanya mengakibatkan perubahan dimensi sekitar $0-0,2 \%$, hal ini masih dalam batas tolerensi klinik ${ }^{10}$.

\section{KESIMPULAN}

Terdapat pengaruh lama perendaman cetakan alginat dalam larutan desinfektan glutaraldehid 2\% terhadap stabilitas dimensi. Rerata paling besar perubahan dimensi cetakan alginat setelah direndam dalam larutan glutaraldehid $2 \%$ adalah $30,57 \mathrm{~mm}$ dan rerata paling kecil perubahan dimensi cetakan alginat setelah direndam dalam larutan glutaraldehid $2 \%$ adalah $30,74 \mathrm{~mm}$.

\section{DAFTAR PUSTAKA}

1. Arinawati, D.Y. Uji Temperatur Air Pencampur Terhadap Setting Time Bahan Cetak. Insisiva Dental Journal, 2012, Vol. 1, No. 1,h. 56

2. Craig, R.G. Restorative Dental Material. 12th ed. St. Louis: Mosby; 2006, h. 272; 274-275

3. Febriani, M. Pengaruh Penambahan Pati Ubi Kayu Pada Bahan Cetak Alginat Terhadap Stabilitas Dimensi. Insisiva Dental Journal, 2012 Vol. 1, No. 1

4. Walker, M.P; Jason, B; David, A.M; Karen, B.W. Dimensional Change Over Time of Extendedstorage Alginate Impression Materials. Diakses 19 April 2013 dari http://www.scribd.com/ doc/45323472/Dimensional-Change-OverTime-of-Extended-storage-Alginate, 2010

5. Wibowo, T; Kristanti, P; Dwi, H. Proteksi Dokter Gigi Sebagai Pemutus Rantai Infeksi Silang. Jurnal PDGI, 2009, Vol. 58, No. 2, h. 6-7

6. Melilli, D; Antonio, R; Angelo, C; Giuseppe P. The Effect of Immersion Disinfection Procedures on Dimensional Stability of Two Elastomeric Impression Materials. Journal of 
Oral Science, 2008, Vol. 50, No. 4, h. 441-446

7. Amin, W.M; Muna, H.Al-Ali; Sandra, K.Al Tarawneh; Sahar, Th.Taha; Mohamed, W.Saleh; Nadia.E. The Effects of Disinfectants on Dimensional Accuracy and Surface Quality of Impression Materials and Gypsum Casts. Journal of Clinical Medicine Research, 2009, 1(2):81-89

8. Bustos, J; R.Herrera; U.Gonzalez; A.Martinez; A.Catalan. Effect of Immersion Disinfection with 0,5\% Sodium Hypochlorite and 2\% Glutaraldehyde on Alginat and Silicone: Microbiology and SEM Study. International Journal of Odontostomat, 2010, 4(2):169-177

9. Pang, S.K dan Brian, J.M. Cross Infection Control of Impressions: a Questionnaire Survey of Practice Among Private Dentists in Hongkong. Hongkong Dental Journal, 2006, 3:89-93

10. Syafiar, L. Dimensional Stability of Alginates Impression Material After Immersion in Mixed Disinfectant Solutions. KPPIKG Indonesia, 2009, h. 270-275

11. Febriani M; Herda E. Pemakaian Desinfektan Pada Bahan Cetak Elastomer. JITEKGI, 2009, 6(2): 41-44

12. Imberly, TA; Nehring J; Janus C; Moon PC. Accuracy and Dimensional Stability of Extended-pour and Conventional Alginate Impression Material. Diakses 23 November 2013 dari http://jada.ada.org/content/141/1/32. full, 2010

13. Jeddy. Pengaruh Empat Macam Perlakuan Pada Bahan Cetak Alginat Terhadap Perubahan Dimensi. Dentika Dental Journal, 2001, 6(1): 1-5

14. Anusavice, K.J. Phillip's Buku Ajar IImu Bahan Kedokteran Gigi (terj). Edisi 10. Jakarta: EGC; 2004, h. 93-111

15. Nandini, VV; K Vijay Venkatesh; K Chandrasekharan Nair. Alginate Impressions: a Practical Perspective. Journal Conservative Dentistry, 2008, Vol. 11(1) 